\title{
Distance Education: Exploring Trends and Issues in the Global
}

\section{Context}

\author{
Jay M. De Loreto ${ }^{1}$ Crissa M. De Loreto ${ }^{2}$ Mely A. Aveno ${ }^{3}$ \\ ${ }^{1}$ Assistant Professor, Education Department, Northern Quezon College Incorporated \\ Brgy. Comon, Infanta, Quezon 4336, Philippines \\ ${ }^{2}$ Private School Teacher, Mt. Carmel School of General Nakar, Inc. \\ Brgy. Anoling, General Nakar, Quezon 4338, Philippines \\ ${ }^{3}$ Public School Teacher, Banugao Elementary School \\ Brgy. Banugao, Infanta, Quezon \\ Corresponding Author: Jay M. De Loreto \\ E-mail: jaydeloreto@yahoo.com.ph
}

\begin{abstract}
With the end goal of informing school management practices, this paper presents a comprehensive review of literature and studies on the trends and issues of Distance Education (DE) in the global context. Due to the development of communication technologies, the change in the modes of Distance Education is very abrupt. Internationalization, cost-effectiveness, access, infrastructure, and quality are some of the trends being faced by our contemporary education system. However, the literature and research findings also revealed that there are some emerging issues in the field such as dropout rates, assessment of students, student concerns, costeffectiveness, issues related to technology use, and infrastructure.
\end{abstract}

Keywords: Distance Education, trends, issues, e-learning, education, Open University

DOI: $10.7176 / \mathrm{JEP} / 11-4-15$

Publication date: February $29^{\text {th }} 2020$

\section{Introduction}

Distance Education is an answer to the emerging needs of diverse learners worldwide. It creates opportunities for learning and employment by sharing the needed information and expertise from the institutions that have created impacts in their respective fields. Rahman, Karim, and Byramjee (2015) reported that it is a trend in education and this trend is rising. Its main purpose is to ensure that students are provided access to quality education through relevant educational materials and guidance from their online teachers (Sadeghi, 2019). However, unlike traditional schooling which has face-to-face interaction between teachers and students or among students, Distance Education delivers instruction through a platform that assumes independence of learners for the tasks of a given course. It is supported by open learning- a philosophy that explains that learning is possible by enabling learners in a learner-centered and flexible learning environment that satisfies their needs (Fraser \& Dane, 1997).

In its very technical aspect, Distance Education is defined as a mode of educational delivery whereby teacher and learner are separated in time and space and instruction is delivered through specially designed materials and methods and supported by organizational and administrative structures and arrangements (Commission on Higher Education [CHED], 2008). As technology improves communication in education, this alternative delivery of instruction is also offered for every interested learner through organizational supports from organizations and governments.

Rashid and Rashid (2012) listed some facts about Distance Education. They are as follows: distance education is a non-formal mode of education that expands educational opportunities; the future of distance education is linked with the advent, development, and integration of new technologies in education; the wide acceptance of Distance Education has been attributed to several considerations which are particular in each country; the increased demand for higher education prompted the utilization of this alternative way to provide access to education, and its cost is much lower than in traditional schooling. With these facts, it is truly evident that DE is an emerging phenomenon that needs to be understood to inform school management practices. 


\section{Distance Education as an Emerging Phenomenon in Global Education}

As innovations emerge, trends in distance education emerge (Sayk1l1, 2018). The development of online learning has shifted from within the country system into a broader and more complex system (Lane, 2010). Worldwide initiatives were done to provide access to open educational opportunities through crash courses, diploma or degree programs. Various online programs in different countries have been installed as part of Distance Education initiatives. For instance, universities and colleges in Asia are relying much on their DE programs to accommodate international students as well as domestic students who cannot attend traditional schooling. There are at least seventy (70) higher education institutions that offer educational services to almost ten (10) million students (Universitas Terbuka Report, 2016). On the other hand, Zormanová (2016) reported that DE in various countries in Europe has been considered important and differs when it comes to levels of development. However, the literature and studies conducted in the African continent attested that they see DE as an important resource to improve their educational system. For instance, South African researchers explore the early adjustment experiences of their undergraduate distance education students (Mittelmeier et al., 2019).

Today, the presence of global educational reform especially in the field of DE is very evident. To provide a more comprehensive view of the phenomenon, the authors will introduce how edX (an organization which was created by Harvard University and Massachusetts Institute of Technology) shape distance education.

With their collaboration, the American, European, Australian, and Asian universities and top organizations in the world such as Microsoft and Amnesty International offer training in their respective specialized fields through edX. The educational programs here are offered through an online platform that is being managed by staff through an organized mechanism for sharing information, taking polls, discussions, assessment of student learning, and the like. For Massive Online Open Courses (MOOCs) that this organization offers, the students would be informed about the course and the learner may opt to choose 'Audit this Course' or 'Verified Certificate'. Here, every student has the choice to audit the course or to take the course freely. It means that everyone who is enrolled can participate in daily activities designed, however, they would not receive a certified from edX. On the other hand, the students may choose 'Verified Certificate' to receive a valid certificate from the institution with the signature of the professor after having completed and passed the requirements of the course.

Using this online learning platform, one thousand nine hundred plus (1900+) courses are offered such as humanities, math, and science, with fourteen million-plus $(14,000+)$ learners worldwide representing every country, and fifty-two million-plus (52 Million +) enrolment across the edX courses (edX, 2019). Thus, it strongly indicates that Distance Education is an emerging phenomenon in global education. However, its inception cannot be fully understood unless there will be a comprehensive presentation of trends and issues that explain its very nature.

\section{Trends in Distance Education}

As an evolving institution, Distance Education is influenced by technological enhancement that creates trends in a local and international setting. These are accessibility, infrastructure, internationalization, cost-effectiveness.

3.1. Accessibility

The advancement in modern technologies has impacted the way how people find ways to access quality education through non-formal delivery mode. Access to the Internet gives more opportunities for students to participate with the teacher and other learners even outside a country. This trend is also supported by the institution of Transnational Education (TNE) in universities. For instance, even an ordinary teacher from a developing country can participate in the leading programs of Harvard University through the MOOCs. With these opportunities, it is evident that Distance Education provides greater access to information and opportunities that shape human lives.

\subsection{Infrastructure}

Distance Education's platform has become more advanced through modern technologies such as online classrooms (e.g. Moodle and Edmodo) and other usable media (e.g. Facebook, Yahoo Mail, and Gmail). Today, students and their teachers can have an online discussion, polls, and students can interact. Sheeja (2011) reported that technological developments allow new paradigms of access and new delivery systems which are linked to new types of demand. 


\subsection{Internationalization}

Globalization shapes education through programs that accommodate learners from diverse societies. An intergovernmental agreement on Transnational Education (TNE) helps to carry out this worldwide initiative (Mellors-Bourne, Jones, \& Woodfield, 2015). Through the change in infrastructure, the so-called home-based internationalization is becoming cost-effective. For instance, the South Ville International School (SISC) in Las Piñas City, Philippines is offering International Baccalaureate (IB) Programs through the help of distance education delivery. There, they utilize online platforms as a means to accommodate international students.

\subsection{Cost-effectiveness}

Distance Education cuts the cost of travel because programs are already available online. In the Philippines for example, students can participate in classes in open universities through online portals. This minimizes the costs of going to university campuses which are commonly situated in cities. Also, working students find Distance Education as an efficient way of improving their career by participating in online classes using the virtual classroom.

\section{Issues in Distance Education}

As learning institutions offer alternative programs to accommodate diverse learners in the local communities and the world, issues such as quality, dropout rates, assessment of students, student concerns, cost-effectiveness, problems related to technology use, and infrastructure are emerging.

\subsection{Maintenance of Academic Standards}

Due to the large enrolment in Distance Education, the maintenance of standards is becoming an issue (Rashid, 2012; Sheeja, 2011). In this alternative mode of schooling, there is no close interaction between students and the facilitator and among students. This situation creates questions in terms of ensuring quality education that should be gained by the students. In fact, Feeler (2012) concluded that the students' perception of instructors' presence is one of the major factors that determine the success of Distance Education.

\subsection{Dropout Rates}

When Massive Online Open Courses (MOOCs) students experience problems in their education, many of them don't continue their studies. Radovan (2018) asserted that many studies have attested that the dropout rate is higher in Distance Education than in traditional programs. Distance Education assumes the independence of learners, high level of motivation, and time management. Due to a very different learning environment in a virtual classroom, students experience 'culture shock' and often quit in their studies. This claim is supported by the research of Brubacher and Silinda (2019) who found out that enjoyment is the predictor of academic success in the DE program rather than competence.

\subsection{Assessment of students}

Monitoring student learning shall be one of the primary concerns of learning institutions. In the context of Distance Education, there is always an issue about the assessment of learning. For example, the instructor cannot easily monitor each progress due to the limitations of the available online learning platforms and conducive environment for assessment of learning (Akhter \& Akbar). However, there are global online portals that provide a quality education through various initiatives for teaching and assessment like Moodle, Edmodo, Google Classroom, etc. Using these emerging media and technology for teaching and learning, global institutions of learning start offering programs that assess the students using closed-ended and open-ended questions that enhance learning.

\subsection{Cost-effectiveness}

Establishing and maintaining online programs involve marginal costs. As institutions widen the horizon to open opportunities for Distance Education, the utilization of high technology is becoming a very important need. Sheeja (2011) asserted that offering properly designed distance learning programs is very expensive. As a result, institutions that cannot jive with the trends in Distance Education find it hard to maintain the operation of the system. 


\subsection{Problems related to technology use}

The advancement of modern technology doesn't ensure the effectiveness of Distance Education. Sheeja (2011) pointed out that teachers or facilitators should be trained on the online system. School administrators should be open to innovations and reforms in education. These small but important efforts critically define the future of distance education in the global context because it is found out that many students have a negative attitude towards Distance Education (Saroha, 2014). With these, students can appreciate educational innovations and will have a positive attitude towards Distance Learning.

\subsection{Infrastructure}

The emerging needs of the education sector, especially in the field of online education, create additional necessities for delivering educational institutions. In developing countries, adequate telecommunication and fast internet connections are necessary. However, it is reported that there are many instances where government support is lacking that hinders the development of Distance Education initiatives, especially in developing countries. The World Bank Group, for instance, recommended some relevant policy directions for the Philippine Government especially the Local Government Units (LGUs) (World Bank Group \& Australian Aid, n.d.). With this, infrastructure projects of any government are seen as responsible actors to ensure the quality of online programs that it offers.

\section{Conclusions}

In light of the research findings which are cited here, the authors conclude that globally, Distance Education is considered as a new approach that enhances access, quality, cost-effectiveness, and equity. Distance mode of education offers an opportunity to study regardless of geographic, socio-economic and other constraints through the ICT revolution that expands the scope of distance learning.

The development of technology allows new paradigms of access and new delivery systems. Despite all the potentials of distance learning, educational leaders are tasked to resolve the critical issues. Quality, costeffectiveness, assessment, lack of motivation and dropout rate, etc. are some burning issues in the field of distance learning. However, the real challenge is the designing of cost-effective and educationally-effective methods of teaching that engage students to pursue their studies. As Goje, Gornale, and Yannawar (2007) suggests, "The increasing numbers of students enrolling in distance learning classes accentuate the need for comprehensive and thoughtful evolution of distance education if it is to become the educational model of the future".

\section{References}

Akhter, N. \& Akbar, R.A. (2015). Problems of distance learners regarding assessment process in Pakistan. Bulletin of Education and Research. Retrieved from https://files.eric.ed.gov/fulltext/EJ1210396.pdf

Commission on Higher Education (2008). Manual of Regulations of Higher Education of 2008. Quezon City, Philippines: Republic of the Philippines- Office of the President. Retrieved from Commission on Higher Education: https://ched.gov.ph/

edX, Inc. (2019). edX. Retrieved January 12, 2019, from https://www.edx.org/

Feeler, W. G. (2012). Being There: A Grounded-Theory Study of Student Perceptions of Instructor Presence in Online Classes. $\quad$ Retrieved January $12, \quad 2019, \quad$ from https://search.proquest.com/docview/1266830430/A75FE19776F146C6PQ/1?accountid=173015

Fraser, S. \& Dane, E. (1997). Why open learning? Australian Universities Review. Retrieved from https://files.eric.ed.gov/fulltext/EJ557068.pdf

Goje, A. C., Gornale, S. S., \& Yannawar, P. L. (2007). Proceedings of the 2nd National Conference on Emerging Trends in Information Technology. Institute of Information Technology.

Lane, A. (2010). Global trends in the development and use of open educational resources to reform educational practices. United Nations Educational, Scientific, and Cultural Organization. Retrieved from https://unesdoc.unesco.org/ark:/48223/pf0000191362

Mellors-Bourne, R., Jones, E., \& Woodfield, E. (2015). Transnational education and employability development. Higher Education Academy. Retrieved from https://eric.ed.gov/?id=ED561344

Mittelmeier, J., Rogaten, J., Long, D., Dalu, M., Gunter, A., Prinsloo, P., \& Rienties, B. (2019). Understanding the early adjustment experiences of undergraduate Distance Education students in South Africa. International Review of Research in Open and Distributed Learning. Retrieved from https://files.eric.ed.gov/fulltext/EJ1223632.pdf 
Radovan, M. (2018). Should I stay, or should I go? Revisiting student retention models in Distance Education. Turkish Online Journal of Distance Education. Retrieved from https://files.eric.ed.gov/fulltext/EJ1221488.pdf

Rahman, M., Karim, R., \& Byramjee, F. (2015). Prospect of distance learning. Journal of International Education Research. Retrieved from https://files.eric.ed.gov/fulltext/EJ1070788.pdf

Rashid, N. \& Rashid, N. (2012). Issues and problems in Distance Education. Turkish Online Journal of Distance Education. Retrieved from https://files.eric.ed.gov/fulltext/EJ976926.pdf

Sabio, R. A. \& Sabio, C. J. (2013). Current Challenges and Prospects facing Distance. Asian Journal of Distance Education. Retrieved January 12, 2019, from http://www.asianjde.org/2013v11.1.Sabio.pdf

Sadeghi, M. (2019). A shift from classroom to distance learning: Advantages and limitations. International Journal of Research in English Education. Retrieved from http://ijreeonline.com/article-1-132-en.pdf

Saroha, R. (2014). Attitudes towards distance learning: A comparative study. International Journal of Information and Computation Technology. Retrieved from http://ripublication.com/irph/ijict_spl/ijictv4n3spl_14.pdf

Sheeja, S. R. (2011). Major trends and issues in the field of distance education. Indian Journal of Science and Technology, Vol. 4 (Third (3rd) Issue ). Retrieved January 12, 2019, from http://www.indjst.org/index.php/indjst/article/view/29965/25920

Southville International School and Colleges (2019). Admission and Enrolment. Las Pinas City, Metro Manila, Philippines. Retrieved from https://www.southville.edu.ph/

Universitas Terbuka (2016). Open and Distance Education trend in Asia. The ICDE President Summit. Retrieved from https://static1.squarespace.com/static/5b99664675f9eea7a3ecee82/t/5c3b2f4840ec9ab9b9ebb337/15473 82607242/day2-tian-belawati+\%281\%29.pdf

World Bank Group \& Australian Aid (n.d.). Assessing basic education service delivery in the Philippines: Highlights from findings regarding teachers. Retrieved January 12, 2019, from www.worldbank.org/ph

Zormanová, L. (2016). Distance Education in European Countries. Jan Ámos Komenský University Prague. Retrieved from https://pdfs.semanticscholar.org/c6c2/ae4f819301f0aa37a1c1513351f9d077ced2.pdf 